\title{
The Impact of Gypsum Application on Groundnut Yield in Rainfed Pothwar: An Economic Perspective
}

\section{Hassnain Shah*, Muhammad Azeem Khan ${ }^{* *}$, Tariq Azeem ${ }^{* * *}$, Abdul Majid ${ }^{* * * *}$, and Abid Mehmood ${ }^{* * * *}$}

\begin{abstract}
This study presents an economic analysis of experimental on-farm data on the yield effect of gypsum on groundnut production in Pakistan's Pothwar region. The data indicates that groundnut pod yield increases significantly with the application of gypsum at $500 \mathrm{~kg} / \mathrm{ha}$ for both local and improved (chakori) varieties of groundnut. The higher net benefits generate a marginal rate of return of up to 132 percent for local and 202 percent for improved varieties of groundnut. We carry out a sensitivity analysis and minimum returns analysis, and find, respectively, that the recommended application is capable of withstanding price variability and variability in yield. Since price structure changes more rapidly than technology, recommendations should be based on an analysis of returns under varying input and output prices.
\end{abstract}

Keywords: Groundnut, gypsum, economic analysis, rate of return, Pakistan.

\section{JEL Classification: Q19.}

\section{Introduction}

The groundnut (Arachis hypogaea L.) crop is one of the world's principal oilseeds. Until the mid-1980s, it ranked third after soybean and cottonseed, but has now been surpassed by rapeseed in terms of world production, closely followed by sunflower seed. ${ }^{1}$

\footnotetext{
* Senior Scientific Officer, National Agricultural Research Centre (NARC) Social Sciences Institute in Islamabad, Pakistan.

*** Senior Director, Social Sciences Institute, NARC.

**** Research Officer, Barani Agricultural Research Institute, Chakwal, Pakistan.

***** Country Officer, International Center for Agricultural Research in the Dry Areas (ICARDA), Islamabad, Pakistan.

***** Director, Barani Agricultural Research Institute, Chakwal, Pakistan.

1 The emergence of rapeseed and sunflower seed may have been due to growing health concerns among industrialized countries and to European Union policy.
} 
The crop's high content of edible oil (50 percent) and protein (25 percent) makes it a popular human food. It is consumed either as a shelled nut or in the form of edible oil after the kernel has been pressed, or in a range of other forms subject to various degrees of processing such as peanut butter, sauce, flour, or confectionery items. Groundnut cake or flour is a valuable ingredient in developing countries where diets often consist mainly of lowprotein cereals. It is also a good source of minerals such as phosphorus, calcium, magnesium, and potassium, as well as vitamins $\mathrm{E}, \mathrm{K}$, and $\mathrm{B}$. In many countries, "groundnuts are not used for oil, ..., but are consumed locally, either fresh, roasted, or as nutmeats added to sweets" (Brookes, Ahmad, \& Hussain, 1988). Additionally, groundnut haulms, whose feed value is similar to that of lucerne seed, are used as animal feed (Ahmad \& Rahim, 2007; Nath \& Alam, 2002; Raw Materials Research and Development Council [RMRDC], 2004). The groundnut is thus one of the most important legume crops and, moreover, enriches the soil with nitrogen without draining nonrenewable energies or upsetting the agro-ecological balance (Khan, Faridullah, \& Imtiazuddin, 2009; Reddy \& Kaul, 1986).

Production by developing countries accounts for over 95 percent of the total area under groundnut cultivation, and about 94 percent of total production, most of which is concentrated in Asia and Africa. In Pakistan, groundnut is cultivated mainly in rainfed areas-about 84 percent of the total groundnut area lies in Punjab, 13 percent in Khyber Paktunkhwa, and 3 percent in Sindh (Government of Pakistan, 2008). Table 1 gives the area and production of groundnut for 2005-2010.

Table 1: Area, production, and groundnut yield in Pakistan

\begin{tabular}{cccc}
\hline Year & Area ('000 ha) & Production ('000 tonnes) & Yield (tonnes/ha) \\
\hline 2005 & 93.71 & 69.13 & 7.38 \\
2006 & 93.50 & 73.90 & 7.90 \\
2007 & 94.90 & 83.40 & 8.79 \\
2008 & 92.80 & 85.50 & 9.21 \\
2009 & 87.40 & 53.20 & 6.09 \\
2010 & 88.00 & 63.00 & 7.16 \\
\hline
\end{tabular}

Source: Retrieved from http:/ / faostat.fao.org on 24 March 2012.

Of the total area under peanut cultivation, 83 percent lies in the Pothwar tract, which contributes 71 percent to the country's total production (Government of Pakistan, 2008). It is considered a cash crop in the rainfed regions of Punjab (Hussain \& Ahmed, 1984). The Pothwar 
Plateau comprises mainly the districts of Rawalpindi, Chakwal, Attock, and Jhelum-an area of over 1 million ha. As a rainfed tract, it accounts significantly for Pakistan's agriculture and livestock production (Supple, Saeed, Razzaq, \& Sheikh, 1985).

The environment in which groundnut is grown (the Pothwar tract) varies considerably in terms of patterns of precipitation and temperature (Hassan, Manaf, \& Ejaz, 2005). Rainfall is erratic and varies greatly from $1,000 \mathrm{~mm}$ in the northeast to $250 \mathrm{~mm}$ in the southwest. The tract lies between $33.38 \mathrm{~N}$ and $73.00 \mathrm{E}$. About 70 percent of 1 million ha is cropped under cereals, mainly wheat, mustard, and chickpeas in winter, and maize, sorghum, groundnut, mung, and mash beans in summer (Hayat, 2005). Groundnut is grown generally in the drier southern part of the Pothwar (Ali, Schwenke, Peoples, Scott, \& Herridge, 2002).

Among other agronomic factors, low-yield varieties and imbalanced nitrogen and phosphorus fertilization are the major constraints to the yield gap of groundnut in Pakistan. In barani cropping patterns, low soil fertility is considered one of the most important problems causing low yield (Khan et al., 1989). In general, soil fertility and organic matter content (0.2-1.2 percent) in barani tracts is low (Ahmad, Davide, \& Saleem, 1988). The nitrogen content of the organic fractions of rainfed soils is merely 0.030.07 percent (Smith, Walls, Rehman, \& Nawaz, 1991), and this is a major factor accounting for inefficient water use and low crop yields in the country's rainfed areas (Khan, Qayyum, \& Chaudhary, 1989).

A multidisciplinary team from different national and provincial agricultural research institutions was organized to address these agricultural productivity issues and, during the course of its work (20012007), also developed and validated a number of groundnut production technologies at the integrated research sites of the Barani Village Development Project (BVDP) in collaboration with the International Center for Agricultural Research in the Dry Areas (ICARDA).

Farmers adopt different components sequentially using economic and other relevant criteria of their choosing (Byerlee \& de Polanco, 1986). Agronomic data only establishes the technical relationships that can be used to determine a technical optimum. This has been done for wheat by Anwar, et al. (2005), for cotton by Javed, et al. (2009), and potatoes by Abedullah, et al. (2006). The "economic optimum" for any input is always lower than the "technical optimum." Thus, it is necessary for biological scientists to conduct economic analyses in a similar manner as they are 
responsible for the statistical analysis of their trials. The usefulness of the results of many biophysical research experiments can be greatly enhanced if the relevant economic analyses can be applied to the results. In this regard, therefore, it makes sense for biological scientists and agricultural economists to jointly evaluate experiments to establish both biological and economic viability.

This study's purpose, therefore, is to contribute to this learning process by developing farm input recommendations that could be useful particularly for multidisciplinary research teams involved in on-farm testing and for policymakers concerned with investment in the dissemination of new technologies based on their rates of return.

Section 2 describes the study's sources of data in the context of the literature and background of the project from which the data has been drawn, and explains the methodology used to analyze this data. Section 3 explains the different techniques of analysis used to assess input recommendations. Section 4 presents and discusses the study's results, Section 5 draws some key policy implications, and Section 6 concludes the article.

\section{Data and Methodology}

Farmers' criteria to evaluate and adopt technologies may be entirely different from that of researchers, and returns on investment in agricultural research cannot be achieved unless farmers adopt researchers' recommendations. Agricultural economists have developed theories and methods of analysis to address the issue of risk-utility analysis (Dillon, 1971) and risk analysis (Anderson, Dillon, \& Hardaker, 1977; Hardaker, Huirne, Anderson, \& Lien, 2004). One approach to developing recommendations for farmers has been to draw on standard production economic theory (Doll \& Orazem, 1984), consider the likely returns on funds invested in new technologies, and ask the question, "What is the likely minimum return on investment (ROI) or marginal rate of return (MRR) that would be necessary for a particular technology to appeal to farmers given that there is variability in likely returns and that they are risk averse?"

This approach was considered particularly useful for farmers in developing countries (International Maize and Wheat Improvement Center [CIMMYT], 1988). Accordingly, using the CIMMYT's approach, we use onfarm experimental data generated by the Barani Agricultural Research Institute (BARI) in Chakwal, Pakistan, at two research sites under the 
BVDP, to develop farm input recommendations aimed at providing valuable information to decision makers in an investment context. ${ }^{2}$

The data from the research trials conducted at the BVDP's two integrated research sites was provided by BARI, which, in turn, was involved in the applied research. Here, we analyze 26 replications of the chakori variety, and 17 replications of the local (farmers' fields) variety. Each selected farmer's field is considered a replication for every year of technology validation, and we have tried to select fields with more or less homogeneous conditions with respect to soil type and fertility level. Most fields were 1 acre large, and contained both experimental and control treatments so that the effect of external factors-particularly variations in soil or moisture, etc.-was equally distributed between the two treatments. The farmers themselves carried out all operations with no difference other than the treatments under study. Information on the prices of inputs and output from the same area was collected during collaborative work at the research sites, while data on gypsum prices was gathered through market surveys conducted among input dealers.

The research trials were conducted systematically and scientifically from site selection, diagnostic analysis, baseline survey, and ongoing trial assessment at farmers' fields. The basic assumptions of conducting diagnostic studies to identify the major constraints to farm productivity and to understand farmers' agronomic and socioeconomic conditions (see Boughton, Crawford, Krause, \& de Frahan, 1990) were fulfilled. Moreover, the procedures assume that the level of net benefit is an important criterion for farmers when they evaluate alternative technologies. An extensive exercise carried out allowed for the selection of representative sites so that the research findings could be extrapolated onto a large representative area. The assumption of homogeneous sites on which to conduct an economic analysis of pooled data is, therefore, also valid (see Shah, Khan, Akmal, \& Sharif, 2005).

In general, two apparently distinct types of peanut (Arachis hypogea) are grown commercially. One is upright with an erect central stem and vertical branches, while the other is recumbent with numerous creeping laterals (Hassan et al., 2005). On-farm trials of the application of gypsum to

2 A number of studies have used the same methodology to conduct economic analyses of experimental data, including Agbaje, Saka, Adegbite, and Adeyeye (2008); Asumadu, Sallah, BoaAmponsem, Manu-Aduening, and Osei-Bonsu (2004); Demeke (1999); Dillon and Hardaker (1993); Saka, Adeniyan, Akande, and Balogun (2007); Shah, Hussain, Akhtar, Sharif, and Majid (2011); and Shah, Sharif, Majid, Hayat, and Munawar (2009). 
both the improved or chakori variety with vertical branches, and to the local variety with creeping branches, were conducted at farmers' fields at two sites-Hafizabad in district Attock and Jarmot Kalan in district Rawalpindi-from 2002 to 2005. The data was generated to assess the crop's response to gypsum application at the rate of $500 \mathrm{~kg} / \mathrm{ha}$ at the flower initiation stage along with control treatment with no gypsum application. Since the technologies were being validated on-farm after proper testing and evaluation at research stations, only that input level that proved promising was further evaluated at farmers' fields. ${ }^{3}$

\section{Analysis Techniques}

\subsection{Partial Budget Analysis}

We carry out a partial budget analysis to calculate gross field benefits $\left(G B_{f}\right)$ as follows.

$$
G B_{f}=P_{f} \times Y_{a d j}
$$

$P_{f}$ is the output's field price, defined as the value of $1 \mathrm{~kg}$ of the output to the farmer, and $Y_{a d j}$ is the adjusted yield of a treatment, i.e., the average yield adjusted downward to a certain percentage to reflect the difference between the experimental yield and the yield that a farmer could expect from the same treatment without the researchers' involvement.

We calculate the net benefit (NB) by first calculating the total costs that vary (TCV), using the field prices of inputs. TCV is the sum of individual costs that vary among different treatments whereas the field price of a variable input is the value that must be given up to bring an extra unit of input into the field. The NB is calculated as follows.

$$
N B=G B_{f}-T C V .
$$

\subsection{Marginal Analysis}

There are four steps in a marginal analysis, identifying a candidate recommendation: (i) identifying and eliminating inferior treatments (dominance analysis), (ii) constructing an NB curve, (iii) calculating the MRR between treatments of incremental cost, and (iv) comparing MRR to the minimum rate acceptable to farmers (Boughton et al., 1990; CIMMYT,

\footnotetext{
${ }^{3}$ It could be very useful if researchers were to experiment and collect data at further levels for such experiments so that the marginal analysis could give a comparative picture of the rate of returns.
} 
1988). We carry out a marginal analysis to calculate the MRR between the incremental NB $(\partial N B)$ and the treatments of incremental cost $(\partial T C V)$, and compare the MRR to the minimum rate acceptable to farmers using the following equation:

$$
M R R=\frac{\partial N B}{\partial T C V} \times 100
$$

In order to make recommendations based on the marginal analysis, it is necessary to estimate the minimum acceptable rate of return (M) to farmers in the recommendation domain. Experience and empirical evidence have shown that, for resource-poor farmers, the minimum MRR is typically $50-100 \%$ (CIMMYT, 1988; Erenstein, 2009; Makinde, Saka, \& Makinde, 2007). A technology change with an MRR of less than 50 percent will not have many takers whereas a technology change with an MRR of more than 100 percent is likely to generate widespread interest (Erenstein, 2009). Usually, a minimum rate of return is fixed as the baseline for acceptance of an option in order to account for the cost of capital, inflation, and risk. In this regard, several studies have established that, in most situations, the minimum rate of return acceptable to farmers is 40-100 percent (Asumadu et al., 2004; CIMMYT, 1988; Dillon \& Hardaker, 1993).

We set a minimum-rate-of-return criterion of 50 percent (see CIMMYT, 1988) for the MRR analysis, since the treatments require that farmers change from one cropping system to another without having to learn new skills or acquire new equipments. Consequently, farmers are likely to consider worthy of investment any treatment that generates an MRR above 50 percent. Regarding investments of a capital nature, the CIMMYT (1988) proposes that a minimum ROI of twice the cost of capital could be a relevant measure for capital investments in new technologies. Alternatively, especially for poor farmers in developing countries or for technologies requiring substantial change to a farming system, a minimum target ROI of 100 percent (the two-for-one rule) is likely more relevant in our case (Farquharson 2006; Shah et al., 2009).

\subsection{Minimum Returns Analysis}

Conducting a minimum returns analysis is a useful way of examining the variability associated with different technological alternatives. Looking at cross-year variability helps estimate the risks for farmers associated with the proposed recommendation. Minimum returns analysis does not look at averages, but rather at variability in the NB 
generated at individual sites. Farmers will prefer whichever treatment is more consistent. A minimum returns analysis compares the average of the lowest NB for each nondominated treatment. The NB at each location for each treatment is calculated as

$$
N B=\left(Y \times A \times P_{f}\right)-T C V
$$

where $Y=$ yield at one location, $A=1-$ yield adjustment, $P_{f}=$ field price of output, and TCV = total costs that vary.

Approximately 25-30 percent of the lowest NB are selected for one treatment and compared with the $25-30$ percent lowest $\mathrm{NB}$ of the alternative. If the average of the lowest $\mathrm{NB}$ for the tentative recommendation is higher than the lowest NB of the farmers' practice, then the recommendation is made because even in the worst cases, it does better than the latter.

\subsection{Sensitivity Analysis}

A sensitivity analysis of different interventions is conducted to test a recommendation's ability to withstand price changes, and essentially implies redoing a marginal analysis using alternative prices. It allows us to calculate the maximum acceptable field price of an input with the minimum rate of return:

$$
\Delta T C V=\frac{P_{f} \times \Delta Y_{a d j}}{1+M}
$$

where

$$
\Delta T C V=\Delta q_{i} \times M P_{i}+t_{i}
$$

$\triangle T C V=$ change in TCV,$\Delta q i=$ change in variable input, $t_{i}=$ cost of labor to apply variable input, $M P_{i}=$ maximum acceptable price of variable input.

\section{Results and Discussion}

\subsection{Net Benefit}

In Table 2, we construct a separate partial budget for local and improved varieties of groundnut to calculate the net benefit of each, and compare farmer practice T1, i.e., without gypsum, and T2, i.e., with 
gypsum application. The results of the partial budget indicate that the use of gypsum generate the highest net benefit, both for the local and improved (chakori) variety of groundnut. In this case, the TCV only includes the cost of gypsum, its transportation, and application. Although the trials were conducted in a participatory manner, we have adjusted the yield to 10 percent lower to eliminate the advisory role of scientists. Our estimates use the 2004 price level for gypsum and groundnut, and the 2004 wage level.

Table 2: Partial budget analysis

\begin{tabular}{lrrrr}
\hline & \multicolumn{2}{c}{ Local variety } & \multicolumn{2}{c}{ Improved variety } \\
\hline Partial budget & $\mathrm{T} 1$ & $\mathrm{~T} 2$ & $\mathrm{~T} 1$ & $\mathrm{~T} 2$ \\
Pod yield (kg/ha) & $1,043.3$ & $1,185.4$ & $1,175.6$ & $1,360.4$ \\
Ad. yield (kg/ha) & 939.0 & $1,066.8$ & $1,058.0$ & $1,224.3$ \\
Field price (PRs/kg) & 726.0 & 726.0 & 726.0 & 726.0 \\
Gross field benefits (PRs/ha) & $17,043.2$ & $19,363.5$ & $19,204.0$ & $22,222.1$ \\
Gypsum level (kg/ha) & 0.0 & 500.0 & 0.0 & 500.0 \\
Cost of gypsum & 0.0 & 900.0 & 0.0 & 900.0 \\
Cost of gypsum application & 0.0 & 100.0 & 0.0 & 100.0 \\
TCV & 0.0 & $1,000.0$ & 0.0 & $1,000.0$ \\
NB & $17,043.2$ & $18,363.5$ & $19,204.0$ & $21,222.1$ \\
\hline
\end{tabular}

Source: Authors' estimates.

\subsection{Marginal Rate of Return}

The results for the introduction of gypsum application to the local groundnut variety were found very satisfactory-the marginal NB was PRs 1,320.30 per ha with a marginal cost of PRs 1,000 per ha, resulting in an MRR of 132 percent. This is considerably high and makes the application of gypsum to the local variety of groundnut worth recommending. The improved variety also responded positively to the application of gypsum, with a higher MRR of 201.8 percent (the marginal NB was PRs 2,018 per ha with the same marginal cost of PRs 1,000 per ha). Our results show, therefore, that the farmer would gain an additional PRs 1.32 as returns on every one rupee invested in gypsum applied to the local groundnut variety, and an additional PRs 2.018 as returns on every one rupee invested in gypsum applied to the improved (chakori) variety. Thus, on the basis of marginal analysis, the technology appears to be highly profitable and should be recommended for wide-scale demonstration and adoption. 
However, farmers would gain maximum benefits if they were to adopt the improved variety in addition to gypsum application.

The results of the marginal analysis are supported by the residual analysis, which is often used when there are more treatments with very little variation in the MRR. In that case, farmers are mostly interested in whichever treatment yields the highest residual value. The results of the analysis using residuals gives a similar picture, as the residual value is maximum for the treatment already recommended through marginal analysis.

\subsection{Minimum Returns Analysis}

Looking at cross-location and cross-year variability is one way of estimating risk for farmers associated with the proposed recommendation. The careful definition of recommendation domains attempts to eliminate cross-location variability as far as possible. Cross-year variability, however, is estimated here based on the results of only two or three years, and tends to underestimate the year-to-year variability that farmers face. Nevertheless, a careful minimum returns analysis is a useful way of examining the variability associated with different technological alternatives. It is worth noting that farmers are more interested in variability in benefits than variability in yields; a minimum returns analysis looks at variability in NB (CIMMYT, 1988).

Our study used comprehensive criteria to select representative sites at which to carry out the applied research and disseminate the project results across similar zones (see Shah et al., 2005) that would reduce crosslocation variability while making the recommendation. The results of the minimum returns analysis of gypsum application to both local and improved groundnut varieties indicate that the average NB generated by the lowest 25-30 percent of replications is higher compared to the withoutgypsum scenario. The average NB yielded by the lowest six of 17 replications that did not have gypsum applied to the local variety was PRs 8,270; the average NB with the application of gypsum was PRs 8,538 per ha.

In the case of the improved variety, the value of the NB of six of the 26 lowest-yielding replications was PRs 9,805 per ha without gypsum application, and PRs 10,447 per ha with gypsum application. The NB yielded even by the worst replication was higher in the case of gypsum application than the replication with minimum returns without gypsum replication. In the case of the local variety, only one replication resulted in a 
higher NB, but we can still conclude that gypsum application provides consistent results-it is less risky since the variation in returns from individual sites is smaller for both varieties of groundnut.

\subsection{Sensitivity Analysis}

Gypsum application at the rate of $500 \mathrm{~kg}$ per ha results in a higher adjusted yield of $128 \mathrm{~kg}$ per ha from the local groundnut variety. In our analysis, we have applied a higher price of gypsum (PRs 90 per $50 \mathrm{~kg}$ ) to the study area, while the general market price of gypsum was PRs 40-50 per $50 \mathrm{~kg}$ in other areas in that year. This was due mainly to low demand and, consequently, less interest among gypsum dealers, resulting in low supply and high prices in the study area. The sensitivity analysis suggests that gypsum could be applied to increase the pod yield of local gypsum up to PRs 106.02 per bag while keeping the minimum acceptable rate of return at 100 percent. In the case of the improved variety, the change in adjusted yield was $166 \mathrm{~kg}$ per ha, which resulted in a maximum acceptable field price of PRs 140.90 per bag of gypsum, keeping the MRR at 100 percent.

Markets, inflation, and policies are generally too unpredictable for researchers to forecast prices with any certainty. Recommendations often involve an investment in extension agents' time, field days, pamphlets, or radio programs, and researchers would like to feel that a recommendation is likely to withstand any possible changes in the prices of inputs or crops for at least a few years. The best way to test a recommendation for its ability to withstand price changes is through a sensitivity analysis (CIMMYT, 1988).

Our analysis was carried out to define the range of maximum acceptable prices with varying output prices, keeping the minimum rate of return required by farmers equal to 100 percent (Table 3). Similarly, Table 4 shows the range of returns generated by different input prices when the output price is fixed; Table 5 indicates the varying prices of output when the input price is fixed. These results help anticipate the recommendation's validity and the possible returns on the specified domain under changing prices. On assessing these returns, farmers may decide to adopt different price scenarios. It also helps define the recommendation's potential given fluctuating market prices. 
Table 3: Different input and output prices resulting in $100 \%$ MRR by variety

\begin{tabular}{cccc}
\hline \multicolumn{4}{c}{ Groundnut variety } \\
\multicolumn{2}{c}{ Chakori (improved) } & \multicolumn{2}{c}{ Local (farmer practice) } \\
\hline $\begin{array}{c}\text { Field price of } \\
\text { groundnut } \\
\text { (PRs/kg) }\end{array}$ & $\begin{array}{c}\text { Max. acceptable } \\
\text { field price of } \\
\text { gypsum (PRs/kg) }\end{array}$ & $\begin{array}{c}\text { Field price of } \\
\text { groundnut } \\
\text { (PRs/kg) }\end{array}$ & $\begin{array}{c}\text { Max. acceptable } \\
\text { field price of } \\
\text { gypsum (PRs/kg) }\end{array}$ \\
\hline 15.00 & 2.29 & 15.00 & 1.72 \\
18.15 & 2.82 & 18.20 & 2.12 \\
20.00 & 3.13 & 20.00 & 2.36 \\
25.00 & 3.96 & 25.00 & 3.00 \\
30.00 & 4.79 & 30.00 & 3.64 \\
35.00 & 5.62 & 35.00 & 4.27 \\
40.00 & 6.45 & 40.00 & 4.91 \\
45.00 & 7.28 & 45.00 & 5.55 \\
50.00 & 8.11 & 50.00 & 6.19 \\
55.00 & 8.95 & 55.00 & 6.83 \\
\hline
\end{tabular}

Source: Authors' estimates based on data from the Barani Agricultural Research Institute.

Table 4: Returns under varying input prices keeping output price fixed

\begin{tabular}{cccc}
\hline \multicolumn{4}{c}{ Groundnut variety } \\
Chakori (improved) & Local (farmer practice) \\
\hline $\begin{array}{c}\text { Price of gypsum } \\
\text { (PRs/kg) }\end{array}$ & MRR & $\begin{array}{c}\text { Price of gypsum } \\
\text { (PRs/kg) }\end{array}$ & MRR \\
\hline 3.82 & 0.50 & 2.89 & 0.50 \\
3.25 & 0.75 & 2.45 & 0.75 \\
2.82 & 1.00 & 2.12 & 1.00 \\
2.48 & 1.25 & 1.86 & 1.25 \\
2.21 & 1.50 & 1.66 & 1.50 \\
1.99 & 1.75 & 1.49 & 1.75 \\
1.81 & 2.00 & 1.35 & 2.00 \\
1.66 & 2.25 & 1.23 & 2.25 \\
1.52 & 2.50 & 1.13 & 2.50 \\
1.41 & 2.75 & 1.04 & 2.75 \\
\hline
\end{tabular}

Note: Field price of groundnut $=$ PRs18.15/kg.

Source: Authors' estimates based on data from the Barani Agricultural Research Institute. 
Table 5: Returns under varying output prices keeping input price fixed

\begin{tabular}{cccc}
\hline \multicolumn{4}{c}{ Groundnut variety } \\
Chakori (improved) & \multicolumn{2}{c}{ Local (farmer practice) } \\
\hline Groundnut price (PRs/kg) & MRR & Groundnut price (PRs/kg) & MRR \\
\hline 9.92 & 0.50 & 12.91 & 0.50 \\
11.58 & 0.75 & 15.06 & 0.75 \\
13.23 & 1.00 & 17.21 & 1.00 \\
14.89 & 1.25 & 19.36 & 1.25 \\
16.54 & 1.50 & 21.51 & 1.50 \\
18.19 & 1.75 & 23.66 & 1.75 \\
19.85 & 2.00 & 25.82 & 2.00 \\
21.50 & 2.25 & 27.97 & 2.25 \\
23.16 & 2.50 & 30.12 & 2.50 \\
24.81 & 2.75 & 32.27 & 2.75 \\
\hline
\end{tabular}

Note: Field price of gypsum $=$ PRs2.00/kg.

Source: Authors' estimates based on data from the Barani Agricultural Research Institute.

\section{Policy Implications}

The analysis above provides a number of insights not only for researchers but also for extension agents and policymakers. The main implication is that the economic returns on the recommended investment play a key role in the adoption of technologies, which varies with changes in prices. Technologies are recommended on the basis of their technical optimum without considering the economic optimum under changing price scenarios. Hence, most technologies with a clear difference in yield are not adopted. Farmers' decisions regarding the adoption of a particular technology are backed by the level of returns under changing price scenarios over time and the associated risks. As agriculture becomes increasingly modernized, the relative significance of different factors affecting farm inputs and outputs changes; factors regarded as significant determinants of farmers' decisions at one time may not be relevant at others.

Knowing how farmers react to changes in market forces (Chaudhary, 2000 and Shah 2002) and government measures is important in different ways. The model provided in this study complements agronomic trials and thereby provides a useful tool to help define the technology potential, particularly in situations when the technology supply market is underdeveloped and its on-site price unknown or not necessarily 
representative of future adopters (see Erenstein, 2009). In developing recommendations, price and yield variability risks must be considered. An important implication of developing farm input recommendations when using economic analysis is that it helps extension agents-and ultimately farmers-in better decision-making. Such recommendations help farmers allocate their inputs more efficiently and effectively. Policymakers should thus focus on enhancing farmers' access to information by providing better extension services (see Javed, Adil, Hassan, \& Ali, 2009).

\section{Conclusion}

The results of our economic analysis of experimental data provide sufficient evidence to recommend the application of gypsum to both local and improved varieties of groundnut-the MRR given the prevailing market prices of gypsum is above 100 percent and would be feasible even if the field price were to increase from PRs 90 to PRs 106 per bag for the local and PRs 141 per bag for the improved groundnut variety. The recommended input also appears capable of withstanding variability and risk considerations as shown by the minimum returns analysis and sensitivity analysis. A market survey of input dealers in the area indicates that gypsum was already being sold at very high prices. Its wholesale price was just PRs 45-50 per bag, but few input dealers were trading in gypsum because of its high storage cost vis-à-vis low demand.

If the recommended technology is widely demonstrated, it may help increase its demand, in turn attracting investors and developing competition, resulting in a decrease (competitive pricing) in the price of gypsum. This may further increase the returns to farmers since the MRR would likely rise. Additionally, an analysis delineating the returns under varying input and output prices and maximum acceptable field prices of gypsum under changing output prices would provide a useful guideline for future users adopting this technology. 


\section{References}

Abedullah, Baksh, K., and Ahmad, B. (2006). Technical Efficiency and its Determinants in Potato Production, Evidence from Punjab, Pakistan. The Lahore Journal of Economics, 11 (2), 1-22.

Agbaje, G. O., Saka, J. O., Adegbite, A. A., \& Adeyeye, O. O. (2008). Influence of agronomic practices on yield and profitability in kenaf (Hibiscus cannabinus L.) fiber cultivation. African Journal of Biotechnology, 7(5), 565-574.

Ahmad, N., Davide, J. G., \& Saleem, M. T. (1988, November). Fertility status of soils in dry land areas of Pakistan. In Proceedings of international seminar on dry land agriculture in Pakistan (pp. 22-49). Lahore, Pakistan: Fauji Fertilizer Co.

Ahmad, N., \& Rahim, M. (2007). Evaluation of promising groundnut Arachis hypogaea L. varieties for yield and other characters. Journal of Agricultural Research, 45(3), 185-189.

Ali, S., Schwenke, G. D., Peoples, M. B., Scott, J. F., \& Herridge, D. F. (2002). Nitrogen, yield and economic benefits of summer legumes for wheat production in rain-fed northern Pakistan. Pakistan Journal of Agronomy, 1, 15-19.

Anderson, J. R., Dillon, J. L., \& Hardaker, J. B. (1977). Agricultural decision analysis. Ames: Iowa State University Press.

Asumadu, H., Sallah, P. Y. K., Boa-Amponsem, P. B., Manu-Aduening, J. A., \& Osei-Bonsu, P. (2004). On-farm evaluation and promotion of quality protein maize hybrids in Ghana. African Crop Science Conference Proceedings, 4, 358-364.

Brookes, J. E., Ahmad, E., \& Hussain, I. (1988). Characteristics of damage by vertebrate pests to groundnuts in Pakistan. In Vertebrate pest conference proceedings collection: Proceedings of the thirteenth vertebrate pest conference. Lincoln: University of Nebraska.

Boughton, D., Crawford, E., Krause, M., \& de Frahan, B. H. (1990). Economic analysis of on-farm trials: A review of approaches and implications for research program design (Staff Paper No. 90-78). East Lansing: Michigan State University, Department of Agricultural Economics. 
Byerlee, D., \& de Polanco, E. H. (1986). Farmers' stepwise adoption of technological packages: Evidence from the Mexican altiplano. American Journal of Agricultural Economics, 68(1), 519-527.

Chaudhary, M. A. (2000). Economic analysis of supply response in Pakistan's agriculture. Lahore Journal of Economics, 5(2), 1-17.

CIMMYT [International Maize and Wheat Improvement Center]. (1988). From agronomic data to farmer recommendations: An economics training manual. Mexico DF: Author.

Demeke, M. (1999, June). Agricultural technology, economic viability and poverty alleviation in Ethiopia. Paper presented at the Agricultural Transformation Workshop of the Tegemeo Institute/Egerton University and Michigan State University, Nairobi, Kenya.

Dillon, J. L. (1971). An expository review of Bernoullian decision theory in agriculture. Review of Marketing and Agricultural Economics, 39(1), 380 .

Dillon, J. L., \& Hardaker, J. B. (1993). Farm management research for small farmer development (2nd ed., pp. 173-189. FAO Systems Management Series). Rome, Italy: Food and Agriculture Organization.

Doll, J. P., \& Orazem, F. (1984). Production economics: Theory with applications (2nd ed.). New York, NY: John Wiley.

Erenstein, O. (2009). Assessing innovations lacking developed supply markets: A simple ex ante model applied to rock phosphate use in rice in West Africa. Experimental Agriculture, 45(3), 287-294.

Farquharson, R. J. (2006). Production response and input demand in decision making: Nitrogen fertilizer and wheat growers. Australasian Agribusiness Review, 14(5).

Government of Pakistan. (2008). Crops area and production (by districts), 2007-08 (pp. 116-117). Islamabad: Ministry of Food, Agriculture, and Livestock.

Hardaker, J. B., Huirne, R. B. M., Anderson, J. R., \& Lien, G. (2004). Coping with risk in agriculture (2nd ed.). Wallingford, UK: CAB International. 
Hassan, F., Manaf, A., \& Ejaz, M. (2005). Determinants of oil and fatty acid accumulation in peanut. International Journal of Agriculture and Biology, 7(6), 895-899.

Hayat, R. (2005). Sustainable legume-cereal cropping system through management of biological nitrogen fixation in Pothwar. Unpublished doctoral dissertation, University of Arid Agriculture, Pakistan.

Hussain, N., \& Ahmed, C. R. (1984). Problems of groundnut cultivation in the representative areas of Punjab (pp. 1-14). Lahore, Pakistan: Punjab Department of Agriculture.

Javed, M. I., Adil, S. A., Hassan, S., \& Ali, A. (2009). An efficiency analysis of Punjab's cotton-wheat system. Lahore Journal of Economics, 14(2), 97-124.

Khan, N., Faridullah, \& Imtiazuddin, M. (2009). Agronomic characters of groundnut (Arachis hypogaea L.) genotypes as affected by nitrogen and phosphorus fertilization under rainfed condition. Electronic Journal of Environmental, Agricultural, and Food Chemistry, 8(1), 61-68.

Khan, A. R., Qayyum, A., \& Chaudhary, G. A. (1989). A country paper on soil, water, and crop management systems for dry land agriculture in Pakistan. In C. E. Whitmar, J. F. Parr, R. I. Papendick, \& R. E. Meyer (Eds.), Soil, water and crop/livestock management systems for rainfed agriculture in the Near East region (pp. 88-102). Washington, DC: United States Department for Agriculture.

Makinde, E. A., Saka, J. O., \& Makinde, J. O. (2007). Economic evaluation of soil fertility management options on cassava-based cropping systems in the rain forest ecological zone of southwestern Nigeria. African Journal of Agricultural Research, 2(1), 7-13.

Nath, U. K., \& Alam, M. S. (2002). Genetic variability, heritability and genetic advance of yield and related traits of groundnut (Arachis hypogaea L.). Journal of Biological Sciences, 2, 762-764.

Raw Materials Research and Development Council. (2004). Report on survey of selected agricultural raw materials in Nigeria: Groundnut. Abuja, Nigeria: Author. 
Reddy, L. J., \& Kaul, A. K. (1986). The status and prospects of groundnut production in Bangladesh (pp. 1-51). Dhaka: Bangladesh Agricultural Research Council.

Saka, J. O., Adeniyan, O. N., Akande, S. R., \& Balogun, M. O. (2007). An economic evaluation of intercropping African yam bean, kenaf and maize in the rainforest zone of Nigeria. Middle-East Journal of Scientific Research, 2(1), 1-8.

Shah, H. (2002). An Analysis of Economies of Scope in Irrigated Agriculture in the Punjab (Pakistan). The Lahore Journal of Economics, 7 (2), 1-14.

Shah, H., Hussain, K., Akhtar, W., Sharif, M., \& Majid, A. (2011). Returns from agricultural interventions under changing price scenario: A case of gypsum application for moisture conservation for wheat production under rainfed conditions in Pakistan. World Applied Sciences Journal, 14(2), 363-368.

Shah, H., Khan, M. A., Akmal, N., \& Sharif, M. (2005). Improvement of crop animal systems in the rainfed agriculture of Pothwar (Punjab) to sustain food security and livelihood. Indus Journal of Plant Sciences, 2(Suppl. 1), 149-156.

Shah, H., Sharif, M., Majid, A., Hayat, U., \& Munawar, A. (2009). From experimental data to farmer recommendation: An economic analysis of on-farm trial of UMMB feed for milking animals in rain-fed Pothwar, Pakistan. Livestock Research for Rural Development, 21(8). Retrieved from (http://www.lrrd.org/lrrd21/8/cont2108.htm).

Smith, F. W., Walls, S. B., Rehman, A., \& Nawaz, M. S. (Eds.) (1991). Groundnut production in Pakistan (p. 81). Islamabad: Pakistan Agricultural Research Council.

Supple, K. R., Saeed, I., Razzaq, A., \& Sheikh, A. D. (1985). Barani farming systems of the Punjab: Constrains and opportunities for increasing productivity. Islamabad, Pakistan: National Agricultural Research Centre. 